DOI: $10.24234 /$ wisdom.v17i1.432

Petro IVANYSHYN,

Larysa YOLKINA,

Nina OSMAK

\title{
NATIONOSOPHICAL TYPE OF HERMENEUTIC THINKING IN THE ESSAYS OF YEVHEN MALANIUK: PROPAEDEUTIC ASPECTS
}

\begin{abstract}
Some important propaedeutic aspects of the analysis of the national philosophical interpretation ("national approach") in the essays of one of the prominent representatives of the vistnykivska tradition Yevhen Malaniuk are considered in the article. On the basis of the previous hermeneutic generalization and definition of national-existential methodology, a propaedeutic outlining of the necessary epistemological thesaurus is proposed, which determines the possibility of comprehending the essence and structure of the author's "national approach" that is a national philosophical type of interpretation in the essays of Ye. Malaniuk. It is confirmed that the diverse and versatile publicistic and scientific works of Ye. Malaniuk (literary-critical, cultural, political, historical, philosophical, nation-logical, etc.) is cultural and philosophical in its thematic horizons. In ideological and aesthetic plan, it is rooted in the ideology of volitional nationalism and the national philosophical theory of art ("Shevchenko's aesthetics"). In a methodological sense, the writer's essays emerge as a "national approach" (or method) structured by national imperative and can be considered as one of the invariants (alongside the experiences of D. Dontsov, Yu. Lypa, M.Mukhyn, etc.) of vistnykivska national philosophical (or national-centric) hermeneutics.
\end{abstract}

Keywords: Yevhen Malaniuk, hermeneutics, national philosophy, national approach, essay, literature, vistnykivstvo.

Introduction

An in-depth study of the poetic heritage of Yevgen Malaniuk (1897-1968), undoubtedly one of the greatest Ukrainian writers of the twentieth century, allows with confidence to go beyond the stereotypical outlining of him as an "intellectual" or a "singer" and to turn to more precise interpretations. These interpretations will inevitably outline a prominent writer for us as a thinker and hermeneut. In the case of Ye. Malaniuk, the ancient observation, most clearly formulated probably by Martin Heidegger (1991), is confirmed: "Philosophy and poetry stand on opposite peaks, but they say the same thing" (p. 154). Another confirmation of the writer's interpretive depth of thinking may be the essayistic discourse, the spiritual and historical expanses of which subject him as primarily cultural philosophical or, using the terminology of the author himself, "geocul- 
tural".

\section{The Analysis of Sources and Recent Researches}

Despite of a rather large number of Malaniuk's-knowing works, authored by O. Bahan, Yu. Voychyshyn, M. Krupach, N. Lysenko, M. Nevrlyi, O. Omelchuk, V. Prosalova, T. Salyha, etc., they have almost no interpretation of hermeneutical experience in the poet's essays. On the other hand, in modern hermeneutical studies of $\mathrm{S}$. Kvit, B. Kyrianchuk, Yu. Kovaliv, Z. Lanovyk and others Malaniuk's interpretive concept also didn't find its comprehension. Indirectly to the hermeneutical potential of Ye. Malaniuk's essayistic thinking, one can go out by pushing off from the paradigmatic for vistnykivtsi experience of D. Dontsov, which, in the opinion of Sergii Kvit (2000), "belongs to the romantic tradition of the hermeneutics of Friedrich Schleiermacher and Wilhelm Dilthey (p. 58). A doctoral study on this topic ("Literary essays by Dmytro Dontsov: national-hermeneutical aspects" (Lviv, 2018)) was recently proposed by Victoria Kolkutina. Hryhorii Klochek (1998) was one of the first in the post-colonial period who noted the genetic link of Ye. Malaniuk's methodology and nationalist essays of D. Dontsov, when "every literary phenomenon is recognized, interpreted and evaluated from nationalist positions" (pp. 25-26).

\section{The Purpose of the Article}

Thus, the urgent necessity of comprehending the philosophical and hermeneutical expanses of Ye. Malaniuk's essays as a discursive and artistic expression of his thoughtful comprehension of meaning or truth of national existence arise. Our propaedeutic interpretation will be based on a somewhat phenomenological understanding of some basic concepts that have structured the author's hermeneutic thinking. Consideration of similar regulatory principles within the epistolary and writer's notebooks is also sufficiently perspective, as well as comparing the obtained results with a comprehension of poetic hermeneutical experience (Ivanyshyn, 2008).

Not least because of Ye. Malaniuk was a deep artistic interpreter of existence, that is, above all, a unique practitioner-hermeneutist; he managed to approach the interpretation of the artistic (wider - cultural) reality from the true, philosophically and scientifically correct, hermeneutical positions. Here, first of all, the successful interpretation of the hermeneutical essence of artistic writing, its interpretive function, that is, the tendency to discover the sense, the deepened meaning of being, sinks in the eye. Characteristic, for example, is the examination of the literature on the example of Shevchenko's creative work as the art of word-logos, that is, a word not as a communicative means, but as an evangelical phenomenon, the Word, "fire". Here the poetic interpretation of literature in I. Franko as "fire in the garb of the word" comes to the aid of Ye. Malaniuk. Therefore, it is necessary to be able to distinguish, feel, and, as the essayist's example shows, to interpret, not only academically, scientifically, rationally-positivistic, or "analytically", "word-material", but above all to go to the basis for artistic reality dimension of "word-Logos", "word-fire" (Malaniuk, 1962, pp. 70-71).

This Logos is all the more important to realize that, as Ye. Malaniuk states in his thought about Lesia Ukrainka, "a real artist... is, at the same time, a discoverer". In this way, he interprets the philosophical and hermeneutical essence of artistic creativity - the discovery of deep meanings in the world, the figurative demonstra- 
tion of the true essence of things: "Before him, everyone looked at that, and it seemed to them they saw everything. But as long as the artist objectifies and is aware of the consequences of that vision, then he discovers and shows - and thus is convincing". And convinces not by argument or sophistication, but by "the most alive type" (Malaniuk, 1962, p. 92). Such position of the orientation of literary cognition on ontologically-fundamental semantic layers clearly took shape in the author in the interwar period: "Art in general, poetry - specifically and above all - stand on the border of insights, seeing through the phenomenality of reality, feeling the entelechy of being (Aristotle's term)" (Malaniuk, 1962, p. 393).

As we can see, the hermeneutic type of thinking, discovered by the writer in poetry, organically transfers into the sphere of essayistic reasoning. That is, in the field where, according to modern scholars (S. Kvit, O. Bahan), essays are formed as a special type of interpretation or criticism, for which, paraphrasing the deeply respected by Ukrainian author, Czech critic Frantishek Shalda, the personality of the author (that is, the hermeneutic scale of his thinking), not one or the other method (Malaniuk, 1966, p. 16), becomes the main methodological basis for cognition. That is similar to the essays of M. de Montaigne, G. K. Chesterton, T. S. Eliot, F. Junger and others.

Vistnyk's circle of litterateurs-nationalists, which was founded by D.Dontsov, the editor-inchief of the Literary and Scientific Vistnyk (later - Vistnyk) (1922-1939) in the interwar period, becomes the natural environment of final maturation, flourishing and growing up of both poetic and essayistic thinking of Ye. Malaniuk. Based on the tradition of Shevchenko's national idea, this philosopher succeeded to work out his own system of ideas of "volitional" (or "valid") na- tionalism, the ideology of "self-rule of the nation", ideology of human-, national- and statebuilding, that is adequate to the tasks, which the catastrophic loss of the Liberation Competitions of 1917-20 had set before the people. In the cognitive, epistemological sense, the thinker develops a national-centric philosophy of art as "Shevchenko's aesthetic" and corresponding to it national-centric hermeneutics as a theory and practice of national-existential interpretation (Ivanyshyn, 2005). Dontsov's ideas had considerably influenced the formation of the original methodology and style of thinking of the vistnykivtsi (writers who were published in the journal "Vesnik" and collaborated with D.Dontsov), though not each of them afterwards admitted it. It's no by chance that in 1958 Ye. Malaniuk mentioned that for him and his congeners, the existence in the camp of interned soldiers of UNR Army was divided into two periods: "before the LNV (and thus - D. Dontsov) and after the LNV". And Dontsov's "The reasons of our politics" became "if not the gospel of a generation..., then one of the much books that stood on the verge of a new era and not only Ukrainian" (Malaniuk, 1966, pp. 375-376).

However, as a matter of fact, learning of Dontsov's ideas, his "national ideology" and aesthetics became not a restriction, but rather a stimulus of creating by vistnykivtsi their original concepts, which were not in all identical with the concepts of the thinker. As for Ye. Malaniuk, manifested itself already in the camp period of creative activity and poured out in short-term polemics in 1923. Understanding of this polemics needs separate researches, but it will be important for us to emphasize the outlook and the ideological community, the national-philosophical homogeneity of the members of disputation. In the article "About Dynamism (About Dr D. 
Dontsov's article "About the Young")", Ye. Malaniuk directly points out that they ("young" authors from "The Rainbow") with D. Dontsov "talk about one thing and we also want one thing: a strong Ukrainian literature, a dynamic Ukrainian "poetry" that would create the Ukrainian Revolutionist from the people, and not "worker-peasant" material for Moscow imperialism". And the difference he quite properly saw in the aspect of consideration of problems: young writers spoke about literature as writers (creators), and D. Dontsov as a political philosopher: “... Dr Dontsov puts demands to literature as a politician and from the politician's point of view, we, the literary youth of emigration, treat it from the point of view of art, as artists" (Malaniuk, 2017, p. 219). Therefore, though D. Dontsov's concepts are often broader and structurally clearer in historical-philosophical and state-building dimensions and criteria, Ye. Malaniuk's reflections, especially those concerning the individual authors, are more refined, elegant, not always maximalist and categorical (in contrast to his poetic interpretations).

Not satisfied with the available concepts, Ye. Malaniuk develops his own theory of art. He does this throughout his life, based, like D. Dontsov, above all on national philosophy as a philosophy of national idea, philosophy of national existence. First of all, it is about such his works as "Notes about National Art" (1921), "Thoughts about Art" (1922-1923), "Pro Domo Sua" (1923), "The Last Day of Our Literature" (1931), "Creativity and Nationality" (1935), "The Attack of Microbes" (1935), "Poetry and Poems" (1936), “F. K. Schalda”(1937), "Literature and Creativity” (1958), “Overdue Generation”(1958) etc. Ye. Malaniuk's aesthetics can be described as neo-romantic and can be roughly characterized as follows. Art for him is rooted in national spirituality, the culture of the people. The art country is "deeply anti-democratic", Genius is dominated in it as an immutable monarch and his "squires" - talents. The soul of art is "movement-rhythm-music", which spiritualizes the material and turns it into a work (Malaniuk, 2017, p. 267). The deepest being of every creativity is life, the "life-giving-building truth of the Nation". The end of XIX - the beginning of XX century is a period of spiritual crisis, enlightenment and pseudo-modernism, the decline of the divine, the human and the national in the art. In the Ukrainian context, it is also about the imperial "complex of Little Russian" as "national hermaphroditism", "devastated soul" and "creative feebleness", which can be cured radically by “only one's own state" (Malaniuk, 1966, pp. 3038). Therefore, the national array of artistic creativity is divided by the author in the formallyaesthetic plan into "technically valuable and technically worthless" literature, and in the national-semantic plan into "Ukrainian ... and pseudo-Ukrainian” (Malaniuk, 2017, p. 388). In a situation of without-statehood, national art must become a powerful "spiritual weapon" in the struggle for the "sovereignty of the nation" (Malaniuk, 2017, p. 212).

The theory and practice of interpretation directly depended on this kind of national-centric philosophy of art. In D. Dontsov (2009), it focused on a completely hermeneutical manifestation of meaning, "spirit", "mystery" of the work (p. 297). The experience of the philosophy of life and the spiritual and historical school of V. Dilthey and his followers also became paradigmatic for the vistnykivska interpretation. For them, literature emerged as an interpretation of life, history, and the writer as a "historical being" who "explores history" and "creates history". First of all, the writer interprets the "life-spiritual bases 
of his own people" (Vrubel, 2006, pp. 56-114). Another characteristic feature national philosophical hermeneutics of D. Dontsov and vistnykivtsi was her interdisciplinary character. That is, at the methodological level, it entered into a dialogue with philosophy, psychology, political science, cultural studies, sociology, historiography, religious studies, and other spheres of cognition.

The most expressive was the dialogue of this interpretive system with politics and such disciplines as political philosophy, political science and geopolitics. And this is entirely justified because, as Hans-Georg Gadamer (2000) points out, one of the important prerequisites of interpretation is the "concrete-hermeneutical situation" in which the interpreter is and with which the subject of understanding is directly got contact (p. 301). The political phenomena such as liberation war, without-statehood, occupation, denationalization, national liberation struggle, national revolution, etc., belonged first of all to the dominant constituents of this situation for vistnykivtsi. Therefore, for example, the presence of one's own national state for Ye. Malaniuk is a prerequisite for a full-cost literary process: "Only free, healthy development of a nation in an Independent State is a prerequisite for free and healthy poetry" (Malaniuk, 2017, p. 273).

The important for the national-centric discourse problem of cultural nationalism as a strategy of ensuring the national-spiritual identity, the identity of a nation that is so actively (and often controversially) interpreted by modern political science and post-colonial criticism is characteristic for the writer's national-philosophical thinking. Already in 1923, Ye. Malaniuk comprehends culture (and above all art) as the main guarantor of an independent political and state existence of a nation: "Neither the army, nor the finances, nor politics can be believed as factors that fully ensure the independence of the state. Borders, economic activity, industry and trade are all just the frames within which real living life takes place. And this real life is the inner life of national culture, the life of the immortal and eternal ideas (and the ideas of art in the first place), because the course of historical events, war, victory and defeat, the heyday and decline of states and peoples, the whole lively mass of history is only the materialization of one or the other ideas" (Malaniuk, 2017, p. 275).

However, the expressive political (as well as religious, historical, cultural, metaphysical, etc.) component does not cross out the literary and hermeneutical nature of the essayist's reflections when he disagrees with the art of the word, with, quite in the spirit of Friedrich Schleiermacher, the divinatory (intuitive) search of its meaning, truth, spiritual essence. So, for example, criticizing the attempts of researchers of that time to comprehend T. Shevchenko's creativity by the formal-aesthetic methods, Ye. Malaniuk compares their efforts with the efforts to comprehend the soul of a person by "a surgical knife" that is quite in a spiritual and historical spirit. Instead, his "soul", "national essence", "national individuality" is basic in a genius and in his poetry since he is "the first and greatest manifestation of the independent Ukrainian spirit” (Malaniuk, 2017, pp. 342-343, 346). Because the main thing in the literature is contained not in the mechanical "doing" or belonging to the fashion direction, but in the "irrational, divine inspiration of feeling, talent given by God, inspired creative temperament, therefore, in the factors of spirit, not matter" (Malaniuk, 2017, p. 581).

It is noticeably that Ye. Malaniuk, although it is not the duty of the extra-academic essayist, 
was not only able to characterize the essence of the hermeneutical method of Academician Stepan Smal-Stotskyi successfully as "a national approach", but also involuntarily to offer a successful outlining that should be applied to the national-centric vistnykivska hermeneutics (and also to the essayist's approach himself): "In his (S. Smal-Stotskyi. - authors) ardent struggle for the real Shevchenko ... the direction to the great truth is given: understanding of Shevchenko's creativity and elucidating of his personality are only possible with the national approach to the national genius" (Malaniuk, 1962, p. 37).

Let us consider now the national-centrism as the basic concept that defines the essence of Malaniuk's hermeneutic method - the national approach - as the author's concretization of visnykivskyi way of understanding.

Nation-centrism emerges as a structure of core methodological principles or Kant's "regulative ideas", which determine the ways of traditionalist comprehending and cognition of reality from the position of the national idea or the truth of national existence. From the hermeneutic point of view, nation-centrism emerges as a general-humanitarian, based on the national imperative, national-existential methodology of thinking "in the categories of protection, development and prosperity of the nation, personal and social rank in the name of its freedom and establishment" (Ivanyshyn, 1992, p. 122). In hermeneutics, such a complex of ideas is outlined as a thesaurus - a system of pre-experience principles pre-judgements or pre-knowledge. The national imperative in the essayist is the core principle of the nation-centric interpretation. D. Dontsov introduced this term into the Ukrainian philosophical tradition in his treatise "Nationalism" (1926). In modern national philosophy, this concept is seen as a categorical order in the sphere of think- ing, which impels the understanding consciousness to verification (checking) cognition with religion (Christianity) and the idea of freedom of the people (Ivanyshyn, 2007, pp. 58-59).

In the essays of the writer, we see diverse categorical orders that express the nationcentrism of cognition and understanding of various spheres of national being. The sphere of ideology as a social worldview ("...the European nationalism is and will remain the general idea of our time" (Malaniuk, 1966, p. 254)) and the sphere of the civilizational choice of Ukrainians ("Either Russia or Europe - and the third is not given" and the conclusion: "...only the West" (Malaniuk, 2017, p. 389)), and the sphere of national-state building (“...independent Ukraine grows out of Independent, Sovereign Culture" (Malaniuk, 2017, pp. 293-294)), and the sphere of art of the enslaved people ("...the struggle for the nation and statehood is carried out not only by a sable and cannon, but also by pen and brush..." (Malaniuk, 2017, p. 240)), and the sphere of Ukrainian literature ("Ukrainian poet... by his nature cannot not be a citizen and... a soldier, even against his wish" (Malaniuk, 2017, p. 285)), and the sphere of interpretation of separate authors ("...the only cure, the only rescuing against all... our national diseases is namely Shevchenko's poetry, fiery, volcanic, terrible for its national demonism, - and until this time only it one and no other" (Malaniuk, 1962, p. 75)) and others. It is no by chance that, among other cultural experiences Ye. Malaniuk (1966) searches for the opinions in those authors who are close to his formulas of national imperative, for example, in the mentioned F. Shalda: “...outside the nationality there is neither art nor truth" (p. 18).

In the ontological-existential dimension, we can interpret Ye. Malaniuk's interpretive pre- 
experience as a system, in H.-G. Gadamer's terminology of true pre-judgements of the existential-historical type (Ivanyshyn, 2005, pp. 27-45). This pre-experience is structured by two main nation-centric reflections, which follow from the general formulation of the national-philosophical hermeneutic circle: man and art as parts can be understood only in the context of national existence as a whole, and vice versa. The first of them says that the nation is that defining reality that causes the existence of the individual and his hermeneutic ability. In his reflection "Creativity and Nationality" (1935), comprehending the crisis of European art, the culturologist explains the organic, immanent connection between the nondevastated personality and his national existence, getting rid of which man loses his own essence and humanity. Ye. Malaniuk (1966) notices that the internal causes of the crisis of the last 40-50 years "are directly connected with the universal crisis of the Personality, which, in spite of the mechanistic-materialistic sorcery of the second half of the XIX century and later experiments, however, remains and can only be a national personality, and not a hieroglyph of not-national "all-humanism" or a differential of international "classism" (p. 24).

The second pre-judgement witnesses the fundamental role of national literature for national existence. Ye. Malaniuk writes most clearly about this in his essay "The Last Day of Our Literature" (1931), interpreting literature as a powerful spiritual-creating, nation-building and history-creating phenomenon: “...for us, our literature is a manifestation of the spiritual power of our nation, a laboratory of national ideas, a prophecy about future or a synthesis about the past ways of our history, and finally... a subtle apparatus, so to speak, "a biometer" that allows us to observe and measure the strain of national activity in the deeper and broader meaning of this word" (Malaniuk, 2017, p. 371). That is why the strong art of the word is considered by the hermeneutists as a guarantee of the future liberation of the people: "Art in general and poetry, in particular, is always a measure of the strength of the national spirit of the people. The nation which gives the great poets always gives the great national leaders - this is an undeniable law". And he adds: "The word, the fiery, the inspired, the powerful word always gives birth to a powerful and inspired work" (Malaniuk, 1966, pp. 278-279).

Other national-philosophical concepts: idealism, voluntarism and heroism, which should be researched more carefully in other studies, coordinate with nation-centrism as a dominant hermeneutic idea (imperative, pre-judgement) in Ye. Malaniuk's hermeneutics.

\section{Conclusion}

Thus, even our partial propaedeutic considerations allow us to draw some conclusions. The diverse and versatile publicistic and scientific works of Ye. Malaniuk (literary-critical, cultural, political, historical-philosophical, nation-logical, etc.) is cultural and philosophical in its thematic horizons. In ideological and aesthetic plan, it is rooted in the ideology of volitional nationalism and the national philosophical theory of art ("Shevchenko's aesthetics"). In a methodological sense, the writer's essays emerge as a "national approach" (or method) structured by national imperative and can be considered as one of the invariants (alongside the experiences of D. Dontsov, Yu. Lypa, M.Mukhyn, etc.) of vistnykivska national philosophical (or nationalcentric) hermeneutics. 


\section{References}

Dontsov, D. (2009). Lyst do holovy MUR-u U. Samchuka (Letter to the Head of the MUR U. Samchuk, in Ukrainian). Visnykivstvo: literary tradition and ideas (pp. 294-307). Drohobych: Kolo.

Gadamer, H.-G. (2000). Istyna i metod. T. I. Hermenevtyka I: Osnovy filosofskoi hermenevtyky (Truth and Method. Hermeneutics. Fundamentals of Philosophical Hermeneutics, in Ukrainian) (O. Mokrovolsky, Trans.). Kyiv: Yunivers.

Heidegger, M. (1991). Razgavor na prasiolachnai darogie: Sbornik (Talking on a Country Road: Collection, in Russian). Moskva: Vyssh. shk.

Ivanyshyn, P. V. (2005). Natsionalno-ekzystentsialna interpretatsiia (osnovni teoretychni ta prahmatychni aspekty). Monohrafiia (National-existential Interpretation (Basic Theoretical and Pragmatic Aspects): Monograph, in Ukrainian). Drohobych: VF "Vidrodzhennia".

Ivanyshyn, P. V. (2008). Natsionalnyi sposib rozuminnia $v$ poezii $T$. Shevchenka, Ye. Malaniuka, L. Kostenko (The National Way of Understanding in Poetry of T. Shevchenko, Ye. Malaniuk, L. Kostenko, in Ukrainian). Kyiv: Akademvydav.

Ivanyshyn, V. (1992). Natsiia. Derzhavnist. Natsionalizm. (Nation. Statehood. Nationalism, in Ukrainian). Drohobych: VF "Vidrodzhennia".
Ivanyshyn, V. (2007). Tezaurus do kursu "Teoriia literatury" (Thesaurus to the course "Theory of Literature", in Ukrainian). Drohobych: VF "Vidrodzhennia".

Klochek, H. (1998). Pro metodolohiiu literaturoznavchoi eseistyky Yevhena Malaniuka (About the Methodology of the Literary Critic Essay-works of Yevhen Malaniuk, in Ukrainian). Yevhen Malanyuk: Literature. Historiography. Culturology, Ch.I. (pp. 24-31). Kirovohrad: KDPU.

Kvit, S. (2000). Dmytro Dontsov. Ideolohichnyi portret: Monohrafiia (Dmytro Dontsov. Ideological Portrait: Monograph, in Ukrainian). Kyiv.: VTs "Kyivskyi universytet".

Malaniuk, Ye. (1962). Knyha sposterezhen. Pro$z a$ (Book of Observations. Prose, in Ukrainian). (Vol. 1). Toronto: Homin Ukrainy.

Malaniuk, Ye. (1966). Knyha sposterezhen. Pro$z a$ (Book of Observations. Prose, in Ukrainian). (Vol. 2). Toronto: Homin Ukrainy.

Malaniuk, Ye. (2017). Vybrani tvory (Selected Works, in Ukrainian). Kyiv: Smoloskyp.

Vrubel, L. (2006). Hermenevtyka (Hermeneutics, in Ukrainian). In D. Ulitska (Ed.), Literature. Theory. Methodology (pp. 56114) (S. Jakovenko, Trans.). Kyiv: "Vyd. dim Kyievo-Mohylianska akademiia". 